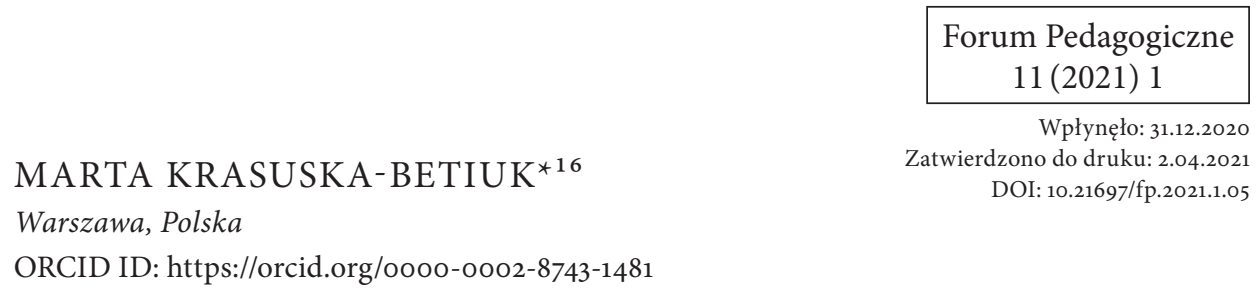

Pycha... Nie ma nic gorszego... Przekonanie, że się umie pisać jest pierwszym szczeblem do klęski...

W związku z tym... ja rzadko piszę

Wiesław Myśliwski ${ }^{17}$

\title{
REPREZENTACJE PISANIA W PEDAGOGICZNYM MYŚLENIU HUMANISTYCZNYM
}

Streszczenie: Osią tematyczną artykułu jest praktyka pisania. Wyrafinowane kompetencje tekstotwórcze posiadają laureaci literackiego Nobla i genialne umysły creative writting. Znacznej grupie ludzi pióra pozostaje całożyciowe rozwijanie i doskonalenie tej umiejętności. Dzięki temu, że sami pisarze i akademicy odkrywają przed światem tajniki swoich biografii lekturowych i zdradzają nam sekrety własnej sztuki pisarskiej, uczenie się od mistrzów jest całkiem realne. Celem artykułu jest prezentacja autotematycznych wypowiedzi na temat pisania wybranych polskich pisarzy, autorów poradników oraz pedagogów. Te propozycje i zaprezentowane obrazy są w istocie reprezentacjami kulturowymi pisarstwa. $\mathrm{Na}$ koniec opracowania przywołano futurystyczne wizje Jacka Dukaja. Uznano bowiem, że epoka postpiśmienna, w której obecnie żyjemy, stanowi ważny kontekst współczesnego i przyszłego pisarstwa akademickiego.

Słowa kluczowe: sztuka pisania, metakompetencje tekstotwórcze, postpiśmienność.

16 Dr nauk humanistycznych Marta Krasuska-Betiuk, mgr filologii polskiej, mgr pedagogiki specjalnej, adiunkt, Akademia Pedagogiki Specjalnej im. M. Grzegorzewskiej w Warszawie, Instytut Wspomagania Rozwoju Człowieka i Edukacji; e-mail: marta.krasuska.betiuk@gmail. com.

17 Wiesław Myśliwski - wypowiedź w programie „Niedziela z...” (2013). TVP S.A. Kultura. Dostępny na: http://ninateka.pl/film/wieslaw-mysliwski-niedziela-z. 


\section{Wprowadzenie}

W autobiografiach, dziennikach i wypowiedziach publicystycznych niejednego twórcy odnajdziemy prywatne historie czytania, wspomnienia ilustrujące mrówczą pracę $\mathrm{w}$ archiwach, przywołujące męki twórcze, towarzyszące dochodzeniu do mistrzostwa czy prace odkrywające poetykę ich dzieł. Relacje te dotyczą pisarstwa artystycznego lub akademickiego, zależnie od gatunku utworu. Dla przykładu, Umberto Eco w harwardzkich wykładach, zebranych w tomie Wyznania młodego pisarza, komentuje szczegółowo, ze zwyczajową swadą, historię powstania i strukturę swych powieści. Adeptom studiów humanistycznych poświęca natomiast poczytny poradnik Jak napisać pracę dyplomową, opracowany w czasach, gdy nie było jeszcze Google’a. Milan Kundera w pracy teoretycznej Sztuka powieści. Esej dokonuje eksplikacji swoich powieściowych idei. Vladimir Nabokov w Pamięci, przemów traktuje pisanie jako radzenie sobie z zapominaniem. Anna Fadiman w esejach z tomu Ex libris pokazała, jak można pisać o czytaniu, a jedną z najpiękniejszych książek o czytaniu i pisaniu jest Jeśli zimowa noca podróżny Itala Calvina. Olga Tokarczuk zawsze nosi przy sobie notesy do zapisywania pomysłów, ze względu na specyficzny rodzaj pamięci. „Literatura” jest najdoskonalszą formą rzeczywistości językowej wytwarzanej przez ludzi. Metafora i narracja są w powszechnym użyciu także tych, którzy nie przeczytali ani jednej książki. Nawet milczenie jest $\mathrm{w}$ istocie cichym czytaniem własnych myśli. Jeśli chcemy mówić lepiej, trzeba czytać lub poddać się nauczaniu tych, co czytają (Koziołek 2016). Pisanie nie jest czynnością naturalną, ludzie muszą się go mozolnie uczyć przez całe życie (Pinker 2016, s. 47). Proponuję poddać się nauczaniu tych, co dużo i dobrze piszą, a celem mojego artykułu jest przedstawienie reprezentacji pisania, zawężonych do refleksji na temat tej skomplikowanej aktywności poznawczej w tekstach wybranych współczesnych polskich twórców i pedagogów. „Literaturoznawstwo (a więc czytelnictwo i pisarstwo) dostarcza narzędzi dekonstrukcji tekstu oraz ideologii go wytwarzającej i pilnującej" (Iwasiów 2020, s. 16).

\section{Stanowisko teoretyczne analizy przekazów autotematycznych}

Teoretycznego uzasadnienia dla reprezentacji pisania jako złożonej aktywności intelektualnej dostarcza m.in zaproponowana przez Monikę Jaworską-Witkowską kulturowa koncepcja pedagogiki - z jej imperatywem przeszukiwania literatury dla zysków pedagogicznych, łączenia poznania literackiego z refleksją pedagogiczną, odkrywania dialektyki czytania. Literatura (czytanie i pisanie) jest dla kulturoznawczyni rodzajem interfejsu dla możliwych dyskursów pedagogiki, który oferuje możliwość przekładu, drogi przejścia z wymiaru do wymiaru, z tekstu do tekstu, z języka do języka, ze rozumienia do jeszcze innego rozumienia. Czytanie i pisanie jest związkiem, który badaczka, za G. Simmlem, nazywa „wybalansowaną jednością" (2009, s. 458). Drugim źródłem inspiracji jest kategoria pedagogicznego 
myślenia humanistycznego, opisana przez Dariusza Kubinowskiego (2006), traktowana jako aktualna kategoria metodologiczna współczesnej pedagogiki zorientowanej humanistycznie. Metodolog, pedagog kultury, wymienił siedem podstawowych cech pedagogicznego myślenia humanistycznego: aksjonormatywność, pryncypialność, holizm, synkretyzm, kontekstualność, diachroniczność i pluralizm metodologiczny. Są one istotne w uprawianiu naukowej twórczości pisarskiej (Kubinowski 2006, s. 177-179).

Pisanie to odtwarzanie tego, co czytane, a zatem w pisaniu ucieleśnia się twarz czytania, inaczej, odtwarza się ciało tożsamości czytelnika i twórcy zarazem. Czytanie i pisanie stanowią "janusowe bramy literatury" i poznania. To jeden dwoisty proces, wzajemnie przenikający się energią twórczą i zasilany jedną, choć złożoną motywacją. Ronald T. Kellog w książce Psychology of Writting przypomina, że pisanie stanowi formę myślenia i jego „instrument” (zakłada się, że ten, kto umie dobrze pisać, umie również dobrze myśleć). Zbyszko Melosik zgadza się $\mathrm{z}$ twierdzeniem podawanym przez Doreen Starke-Meyerring i Anthony Paré w The Roles of Writing in Knowledge Societies, że „cykliczny ruch między mentalnymi reprezentacjami w umyśle a symbolicznymi reprezentacjami na stronie ma charakter generatywny”. Mówi metaforycznie o „podmiotowości” czystej kartki czy czystej strony ekranu, w stosunku do myśli, która jest, co prawda, przelewana na papier bądź ekran, ale tenże proces wizualizacji sam w sobie wpływa zwrotnie na umysł autora. Pisanie jest więc procesem umysłowo-wizualnego doświadczania własnych rekreowanych myśli. Taki sposób myślenia, akcentujący podmiotowość „papieru” w relacji do autora, czy zasadę partnerstwa między nimi, eksponują Keith Oatley i Maja Djikic, które piszą, iż „pisarz eksternalizuje myśli na papier”, następnie zmienia je pod wpływem czytania. Uważają one, że relacja między pisaniem a papierem pozwala na wyłonienie się typu myślenia niemożliwego, bez owej tymczasowej, zewnętrznej pamięci. Papier jest postrzegany w tym kontekście jako „partner konwersacji” (Melosik 2019a). Pisanie jest stanem dynamicznym, albowiem nie kończy się wraz z zaniechaniem tworzenia tekstu, ale pozostaje $\mathrm{w}$ nas tak długo, jak długo jest czytany tekst i organizowane są wokół jego idei dynamiczne motywacje, świadome lub nieświadome. Trwa nieustanna praca pojęć $\mathrm{w}$ profilu epistemologicznym człowieka. W trakcie pisania dokonuje się swoisty scanning pamięci, dynamizowanie pokładów archiwum, nieświadomego czytania i przeszukiwania języków możliwego wysłowienia (Jaworska-Witkowska, s. 459).

Trzeba zgodzić się z Ingą Iwasiów (2020), że we współczesnym świecie panuje epidemia pisania. Język jest jednym z „mediów”, za pomocą którego myśli, idee i uczucia są przedstawiane w kulturze. Reprezentacja w języku i poprzez język ma zatem kluczowe znaczenie dla procesów, w których wytwarzane jest znaczenie (Hall 2013). Użytą w tytule kategorię reprezentacji przyjęłam za badaczkami dyskursu (Duszak 2015; Duda, Przyklenk, Sujkowska-Sobisz 2019) jako odnoszącą się do pewnego typu przedstawień, obrazów, wizji pisania jako aktywności człowieka myślącego. 


\section{Ars poetica tekstów humanistycznych, czyli literaci uchylają rąbka tajemnicy pisania}

Autotematyczny Brewiarz Zbigniewa Herberta zarysowuje program poezji-ideału, ale ma również wymiar retrospektywny, scala poetyckie doświadczenie autora w ramach ukrytego ładu.

\section{Panie,}

obdarz mnie zdolnością układania zdań długich, których

linia jak zwykle od oddechu do oddechu wydaje się

linią rozpiętą jak wiszące mosty, jak tęcza, jak alfa i omega oceanu

Panie,

obdarz mnie siłą i zręcznością tych, którzy budują

zdania długie, rozłożyste jak dąb, pojemne jak wielka dolina,

aby mieściły się w nich światy, cienie światów,

światy z marzenia

a także aby zdania główne panowały pewnie nad podrzędnymi,

kontrolowały ich bieg zawiły, ale wyrazisty, jak basso continuo

trwały niewzruszenie nad ruchem elementów, aby przyciągało

je, jak jądro przyciąga elektrony siłą niewidocznych praw grawitacji

o zdanie długie tedy modlę się, zdanie lepione w mozole,

rozległe tak, by w każdym $\mathrm{z}$ nich znalazło się lustrzane

odbicie katedry, wielkie oratorium, tryptyk

a także zwierzęta potężne i małe, dworce kolejowe, serce przepełnione żalem, przepaście skalne i bruzda losów w dłoni.

Zbigniew Herbert (1998). Brewiarz, Epilog burzy. Wrocław

Konstrukcja modlitwy ikonicznie odzwierciedla podwójne pragnienie: swobodnej formy, przekraczania granic a zarazem odnajdywania się w ramach nadrzędnego porządku, i tęsknotę za dawnym, klasycznym ładem („nikt już dzisiaj takich długich zdań nie pisze" - ironizował Herbert, opisując Klasyka w tomie Hermes, pies i gwiazda) (Mikołajczak 2013, s. 39). Brewiarz należy do wyjątków - wierszy autotematycznych, ponieważ utworów o własnym pisaniu, refleksji o poezji w twórczości Herberta prawie nie ma. Uważa on bowiem, że należy dawać gotowe produkty i nie wypada rozwodzić się nad ich przygotowaniem. Ma to oczywiście także i inne uzasadnienia. Herbert nie zwątpił w wartość sztuki, kultury, w możliwość podejmowania dawnej myśli i używania dawnych słów. Poddaje tradycyjne formy i słowa własnej dykcji, używa ich z umiarem, ale korzysta $\mathrm{z}$ nich stale. „Zdanie lepione w mozole" to nic innego jak pars pro toto poezji. Skoro zatem prosi o taką zdolność, musi mieć wątpliwość, czy do tej pory umiał sprostać temu zadaniu. 
Archiwa pisarzy skrywają dokumenty osobiste, poświęcone biografii czytelniczej i sztuce pisania. Jednym z najważniejszych tekstów traktujących o poetyce reportażu jest monumentalne, liczące w sumie ponad tysiąc stron dwutomowe dzieło Karafka La Fontaine’a, Melchiora Wańkowicza (1972), które zostało pomyślane jako rodzaj przewodnika dla reporterów, ale także jako sui generis - podsumowanie kilkudziesięcioletniej praktyki dziennikarskiej Wańkowicza. W szerokim spektrum zanotowanych z dużą swadą i erudycją wskazówek uwagę zwraca nakłanianie młodych dziennikarzy do lektury. Karafka... nie jest bowiem tylko obszerną wypowiedzią traktującą o sztuce pisania, ale też - a może przede wszystkim - książką zachęcającą do "podglądania” dawnych mistrzów i świadomego, krytycznego czerpania ze źródeł. Wańkowicz staje na stanowisku, iż każdy napisany tekst uwikłany jest w szereg intertekstualnych powiązań, będących efektem lekturowych doświadczeń reportera. Powiada:

[...] ja (samochwała w kącie stała...) dla jednego tylko dzieła [...], w wielkiej swej części spoczywającego na rękopiśmiennych Powązkach, cytowałem źródła z 890 pozycji bibliograficznych, z siedmiu języków (dla jidysz i hebrajskiego przy pomocy sekretarza) (Wańkowicz (1972), Karafka La Fontaine’a, cyt. za: Żyrek-Horodyska 2019, s. 45).

Za kwestię o kluczowym znaczeniu, poprzedzającą napisanie własnego tekstu, reporter uznał rzetelny, oparty na wielu źródłach, research. Charakteryzując swój sposób przygotowywania materiału dziennikarskiego, Kapuściński przyznał: Ja strasznie dużo pracuję nad tekstem, żeby napisać jedno własne zdanie, trzeba przeczytać tysiące cudzych. Reporter wielokrotnie podkreślał, jak istotne jest zapoznanie się z dorobkiem wcześniejszych twórców.

Wiesław Myśliwski ufa językowi, o swoich zmaganiach z materią języka chętnie opowiada w wywiadach.

Linearna, konwencja konstrukcji tekstu mnie nie interesuje, bo ona przy naszym dzisiejszym doświadczeniu nie zdaje egzaminu, nie nadaje się, żeby opisać jakiś kawałek współczesnego świata(...). Bo współczesny świat jest zdezintegrowany, rozbity, w gruncie rzeczy jest ciągle mieniącym się i zmieniającym kalejdoskopem. (...) A gdy chce się oddać świat w sposób syntetyczny, jedynie poetyka chaosu jest adekwatna. Wbrew pozorom chaos wymaga żelaznej logiki. Musi być skonstruowany. Piszący w poetyce chaosu prezentuje pozornie nieprzystające do siebie sprawy, ludzi, zdarzenia, ale to musi mieć logikę (...). Każdym chaosem rządzi logika ${ }^{1}$.

1 Zob. https://artus.torun.pl/rozmowa-z-wieslawem-mysliwskim. 
Marek Bieńczyk w pierwszych zdaniach Książki twarzy zadaje pytanie: Kto z piszących i żyjących nie słyszał porad na temat pisania, kto ich sam sobie nie udzielał, siebie nimi nie łudził, nie torturował?

Pisz, ale też trochę żyj. Pisz, ale nie zapomnij o życiu, tak szybko mija. Pisz, lecz korzystaj z życia, bo nie warto go tracić.(...) Jest czas pisania i czas istnienia, mówią one, zastanów się, tu jeszcze czeka na ciebie las, tam morze. (...). Jednak ciało pamięta, budzi się w środku nocy i w mroku zamiast nas wymyśla do kolejnej strony zdanie, z którego rano pozostaną na ogół strzępki. Ciało pamięta: gdy tylko wstaje, włącza jednocześnie machinalnie, nim jeszcze ustanie ziewanie, ekspres do kawy i komputer; ciało pamięta i choć wykonuje jakieś czynności, kroi chleb, odbiera telefon, to całe zapada się w tekst, jaki właśnie piszemy. (...) I tak życie przechodzi, jakkolwiek krótkie by było, kruche i wciąż nie dość używane. Nie da się oddzielić obu porząaków; tego, co fizyczne, od tego co wysłowione, ciała od zdania, nie da się żyć bardziej, pisać mniej z powodu niewysłowionej konieczności: tak już jest, tak musi być, tak będzie wyglądała do końca ta Vita - życie przeżywane dla słowa (Bieńczyk 2011, s. 6).

Wielu dobrych polskich prozaików pamięta o maksymie More is less. Mikołaj Łoziński mówił: „Pisząc, staram się, aby nie było tam nic niepotrzebnego, często wychodzę z takiego założenia, że mówiąc mniej, można powiedzieć więcej. Staram się, by w moich książkach nie było nic zbędnego".

Rada Mikołaja Grynberga jest taka: „warto dać tekst przed publikacją do czytania zaufanym przyjaciołom dobrze piszącym, nie słuchać fałszywych przyjaciół, którym się wszystko podoba" (http://conradfestival.pl/program).

Jacek Dukaj, którego futurystyczne opisy ery postpiśmiennej przedstawione zostaną w końcowej części artykułu, tak ocenia współczesną komunikację literacką:

Kiedy zaczynałem swoja przygodę z literaturą, język pisarza rozpoznawało się po rozbudowanym słownictwie, elastyczności i złożoności składni, po zindywidualizowanej frazie i wysokiej świadomości językowej. Dzisiaj język profesjonalisty pisma można poznać po prostocie konstrukcji zdań, umiejętności wysławiania się za pomocą tylko tych zwrotów, które „zrozumieją wszyscy", po wyzbyciu się lokalizmów, wszelkich stylizacji i nawyków narracji utrudniających przekład, zwłaszcza przekład na angielski (Dukaj 2019, s. 255).

\section{Styl klasyczny wobec stylu naukowego}

Giganci humanistyki zwykle występują w podwójnej roli - akademików i znakomitych literatów, stąd też podejmują się opracowania podręczników dobrego 
pisania - jak wspomniany we wstępie Umberto Eco. Kognitywista i lingwista Steven Pinker (2016) wykorzystał naukową wiedzę na temat języka i umysłu, aby pomóc czytelnikowi w trudnej sztuce tworzenia przejrzystej, spójnej i stylowej prozy. W rozdziale drugim swojego przewodnika Piękny styl, zatytułowanym Okno na świat, zaleca styl klasyczny jako lekarstwo na żargon specjalistyczny, w tym prozę naukową. Styl klasyczny w prozie opisany został w książeczce Clear and Simple as the Truth, autorstwa literaturoznawców Francisa-Noela Thomasa i Marka Turnera (1994). Jest to styl arystokratyczny, nie egalitarny (Pinker 2016, s. 51). Metaforą tego stylu jest widzenie świata. Autor widzi coś, czego odbiorca jeszcze nie zauważył, i kieruje spojrzenie czytelnika, aby i on mógł to zobaczyć. Celem pisania jest prezentacja, a motyw, który się za tym kryje, to obiektywna prawda. Pisarstwo odnosi sukces, kiedy udaje mu się połączyć język z prawdą, czego dowodem jest jasność i prostota. Prawdę można poznać, przy czym nie jest ona tożsama z językiem, który ją ujawnia; proza jest oknem na świat. Pisarz zna prawdę, zanim jeszcze ubierze ją w słowa - nie wykorzystuje pisania jako sposobności do przemyślenia swojego stanowiska. Autor klasycznej prozy nie musi też podawać argumentów przemawiających za prawdą - musi ją tylko przedstawić. Piszący i czytelnik są sobie równi, a proces ukierunkowania spojrzenia czytelnika przybiera formę rozmowy, czytelnik jest skłonny do współpracy, czyta między wierszami, nadąża za argumentacją i kojarzy fakty. Style pisarskie nie są wyraźnie rozgraniczane. Tekst napisany stylem funkcjonalnym (praktycznym) zwykle jest zgodny z pewnym szablonem i na ogół jest zwięzły, tymczasem tekst napisany stylem klasycznym może przybrać dowolną formę i być dowolnie długi. Zwięzłość stylu klasycznego ,jest wynikiem elegancji umysłu autora, nie zaś presji czasu lub wymagań pracodawcy" (Thomas, Turner 1994, s. 81). Autorzy często łączą różne style pisarskie lub korzystają z nich naprzemiennie. Teksty naukowe często bywają mieszanką stylów funkcjonalnego i autotematycznego. Styl klasyczny jest pewnym ideałem (Pinker 2016, s. 51).

Kultura języka naukowego rządzi się swoistymi prawami, oznacza bowiem stopień umiejętności władania językiem przez uczestników komunikacji naukowej - nadawców i odbiorców, od których oczekuje się przestrzegania prawdy, pełności (dostateczności), jasności, racjonalności, logiki w uogólnianiu i wnioskowaniu (Gajda 2001, s. 193). Wyższy - wystarczający poziom kultury języka naukowego - widoczny jest w wypowiedziach uwzględniających w szerszym zakresie normy komunikacyjne, a więc zorientowanych nie tylko ad rem, ale i ad hominem. Efektywność komunikacji naukowej polega na tym, że odbiorca rozumie nadawcę zgodnie z jego zamiarami oraz może szybko i w pełni wydobyć potrzebną mu informację. Troska o stan świadomości językowej jest wciąż aktualna, wpływają na nią wzorce zawarte w tradycji pisarstwa naukowego, wymogi stawiane przez mistrzów, opiekunów naukowych i recenzentów wydawniczych, postawy filozoficznonaukowe oraz metodologiczne, panujące i przyjmowane w środowisku uczonych, a przede wszystkim samodzielna praca autorów nad ich własnym językiem (Gajda 
2001, s. 194). Pismo stanowi dotąd jądro komunikacji w nauce, a artykuł i mimo wszystko monografia w naukach humanistycznych są podstawowymi gatunkami. Cytowany twórca i propagator opolskiej szkoły stylistyki w wykładzie wygłoszonym na Letniej Szkole Młodych Pedagogów KNP PAN w 2017 roku stawia retoryczne pytanie: Jak stać się dobrym stylistą? Aby na nie odpowiedzieć, trzeba go zacytować: „Nie ma prostych recept. Pomijając kwestię talentu, sądzę, że trzeba nad tym pracować" (Gajda, 2017, s.19) Zaleca lekturę przewodników po sztuce pisania. Wiedza językowa w tym przypadku ma wyjątkowe znaczenie dla pracy poznawczej, dzięki temu, że po pierwsze - umożliwia wyrażanie i transferencję wiedzy, oraz po drugie - umożliwia wytwarzanie wiedzy dzięki swej funkcji epistemicznej (por. Grucza 2015, s. 65). Im głębsza jest wiedza językowa, tym większe są możliwości transferencyjne i kognitywne człowieka. Naukowiec musi swoją wiedzę werbalizować w toku pracy poznawczej i transferencyjnej wykonywanej dla różnych grup odbiorców. Niezbędnym komponentem całkowitej kompetencji człowieka nauki jest jego sprawność tekstotwórcza, którą aktywizuje w toku werbalizacji wiedzy i tworzenia tekstu. Umiejętność tworzenia tekstu, zwłaszcza pisanego, jest cenną i potrzebną umiejętnością w świecie nauki, ale jest to także złożona czynność kognitywna, którą naukowiec podejmuje w każdej fazie swojej pracy poznawczej (Łompieś 2018). Najwyższy stopień wyczucia językowego wyraża się posiadaniem teoretycznonaukowej wiedzy o języku naukowym. Jest ona udziałem nielicznych. Do grona znawców z pewnością zaliczyć można autorów poradników, które wchodzą $\mathrm{z}$ jednej strony w zasięg poradnictwa językowego, z drugiej zaś odwołują się do standardów pisarstwa akademickiego obowiązujących w czasopismach wysoko punktowanych (Ficek 2013). W tekście odwołuję się jedynie do wybranych poradników, których potencjalnym adresatem są autorzy prac naukowych z obszaru nauk humanistycznych i społecznych.

\section{O istocie pisarstwa naukowego}

Maria Janion tak opowiadała w wywiadzie o swoim akademickim pisaniu:

Nie należę do osób, które piszą jedynie w ciszy gabinetu. Nauczanie jest dla mnie motorem mojego poznania i pisania. Metoda jest taka: najpierw myśl trzeba poddać próbie, trzeba ją sformułować wiele razy i to wobec ludzi, których reakcje mogę śledzić. Czasem oni replikują, czasem zadają pytania. W ten sposób myśl przybiera taki kształt, który może zostać zapisany. Robię też notatki - najpierw przygotowując się do seminarium, potem w trakcie, a potem jeszcze po seminarium, żeby zdać sobie sprawę, w jakim stopniu myśl się przekształciła. Jest więc kilka wersji. To jest ciężka praca i kiedyś szło mi to łatwiej, ostatnio zużywam bardzo dużo papieru. Studenci się dziwią, że notuję także słuchając ich referatów, albo podczas ich wypowiedzi. Pewnie to im dobrze robi, bo widzą, że jest ktoś, kto interesuje się nimi, a ja mogę 
przypominać sobie potem te głosy, które mnie otaczają, kiedy piszę (Janion 1997, s. 199).

Zmagania i wysiłki twórcze piszącego akademika mają dwojaki charakter: związane są z dylematami natury metodologicznej oraz z opanowaniem trudnej sztuki (rzemiosła) naukowego opisu zagadnień szczegółowych. Trudności związane $\mathrm{z}$ tworzeniem tekstu naukowego pojawiają się na etapie pracy ze zgromadzonym materiałem (Maćkowiak 2010). Inny problem to „klątwa wiedzy” (Pinker 2016), czyli trudność w wyobrażeniu sobie, jak to jest, gdy ktoś nie wie tego, co my wiemy. Dodać można także paradoksalnie, gdy ktoś wie znacznie więcej o tym, czego my nie wiemy. Owa klątwa wiedzy odnosi się, w przypadku badań społecznych, do świadomości badacza - pedagoga, w taki sposób, że kategorie, którymi się zajmuje (zaufanie, podmiotowość), są dobrze znane np. socjologom czy psychologom, filozofom, jego zaś dylematy (pedagoga) mogą wydawać się w środowisku psychologów lub socjologów banalnymi. Pedagodzy są zobowiązani do śledzenia rozwoju dyscyplin pokrewnych. W czasach błyskawicznej globalnej dostępności za pośrednictwem technik cyfrowych, artykułów i książek na temat interesującej nas problematyki, tego czym się zajmujemy, kwestie nieustannego aktualizowania wiedzy nabrały szczególnego znaczenia.

Konstruowanie tekstu polega na ułożeniu idei w racjonalnym porządku, tak aby nasz artykuł stanowił spójną narrację, był czytelny dla badaczy i reprezentantów społeczności naukowej oceniających nasz potencjał naukowy (Becker 2013). Ponieważ jesteśmy osobami aspirującymi do grona uczonych, musimy doskonalić własny warsztat badawczy i styl pisarski, albo starać się połączyć jedno i drugie, czyniąc z pisania metodę naukową (Richardson, Pierre 2009). Jako autorzy zmagamy się zatem z problemem organizacji tekstu na dwóch poziomach: merytorycznym (poprawność logiczna i empiryczna) i językowym - gdy dążymy do przekazania treści w dobrym stylu (stylowe pisanie naukowe).

Inną trudnością w przygotowaniu tekstu naukowego jest znalezienie właściwego sposobu wykorzystania dostępnych tekstów - selekcja materiału i wyeliminowanie jego nadmiaru, uwzględnienie tradycji badań, dorobku poprzedników, a więc zadania i wysiłki, które Howard Becker (2013) nazwał „terrorem literatury”, a Umberto Eco (2007) - „selekcją materiałów” - źródła z pierwszej ręki i opracowania z drugiej ręki. Pierwszy krok do stworzenia tekstu artykułu stanowi staranna kwerenda bibliograficzna, pozwalająca wyłonić teksty źródłowe (oryginalne), które często okazują się bardzo trudne ze względu na ograniczoną intersubiektywną komunikowalność (Boruszewski 2017) ${ }^{2}$. Dla przykładu, jeżeli czytamy przetłumaczone na język polski eseje Alfreda Schutza pt. Potoczna i naukowa interpretacja ludzkiego działania (zob. Mokrzycki E. (1984). Kryzys i schizma. 1. Antyscjentystyczne

2 Treść publikacji „X” jest intersubiektywnie komunikowalna wtedy i tylko wtedy, gdy kompetentny odbiorca „O” zapozna się z treścią tej publikacji i zrozumie tę treść. 
tendencje $w$ socjologii współczesnej) albo Światły obywatel. Esej o społecznym zróżnicowaniu wiedzy (zob. „Literatura na Świecie” 1985), staramy się je zrozumieć na swój sposób. Jeśli nie do końca rozumiemy oryginalny przekaz, sięgamy do interpretacji Sławomira Mandesa, zawartej w książce Świat przeżywany w socjologii (2012). Dodatkową barierą jest bariera językowa, ponieważ większość materiału źródłowego nie jest dostępna w języku polskim. Nie zawsze poziom językowy badacza umożliwia wierne tłumaczenie wyrafinowanych językowo obcojęzycznych tekstów specjalistycznych.

\section{Trudności w osiąganiu doskonałości językowej o podłożu metodologicznym i pedagogicznym}

Dokonana pod koniec XX wieku krytyczna ocena języka humanistyki Jerzego Pelca (Pelc 200o) pozostaje aktualna. Semiotyk użył określenia „profesjonalny bełkot” wobec tekstów, w których za wyszukaną formą ujawnia się negatywna treść, która wyziera zza zasłony niejasności. Staje się to czynnikiem demoralizacji intelektualnej i uczy oszukiwania pozorami naukowości. Maria Dudzikowa, powołując się na serię wydawaną przez uczonego, i ukutym w niej określeniem, że przebywamy $\mathrm{w}$ „zanieczyszczonym środowisku językowym i intelektualnym”, dostrzegała te niepokojące zjawiska w tekstach pedagogicznych, które pretendują do miana interdyscyplinarnych. Referuje się w nich nie tyle poglądy osadzone w kontekście konkretnej teorii czy orientacji, ile „cytuje się nożyczkami”, tzn. wybiera się jakiś fragment (najczęściej definicję) i wmontowuje we własny wywód jako jego potwierdzenie, choć w kontekście treści i orientacji metodologicznej cytowanego autora jest dokładnie odwrotnie (Dudzikowa 2009, s. 182). Lech Witkowski (2007, s. 50) nazwał takie zabiegi „erudycyjną żonglerką z jednoczesnym brakiem zdolności ukazywania pracy wybranych pojęć".

Bożena Witosz (http://www.rjp.pl) zwraca uwagę na szczególną heterogeniczność przedmiotowo-pojęciową ponowoczesnej metodologii, za którą odpowiedzialny jest jej transdyscyplinarny charakter. Wypowiedź językoznawczyni celnie ilustruje sytuację współczesnego badacza, dlatego przytoczę jej fragment:

Ponowoczesność (...) nakładając na podmiot poznający obowiązek ciągłego poszerzania horyzontów wiedzy i przekraczania granic własnej dyscypliny, nie zwalnia go z obowiązku manifestowania świadomości metodologicznej. Jej wyostrzenie staje się wręcz niezbędne wobec nowych konwencji piśmiennictwa naukowego. Dawną monologowość tekstu naukowego zastępuje dziś dialogiczność: podmiot poprzez tekst rozmawia (dyskutuje, spiera się, szuka potwierdzeń) $\mathrm{z}$ innymi autorami, ale także w rozważaniowym trybie wypowiedzi prowadzi dialog z samym sobą i czytelnikiem. Intertekstualia, które są nieodłącznym składnikiem poetyki wypowiedzi naukowej, dziś występują w nich znacznie częściej, obserwujemy też poszerzanie ich zakresu i funkcji 
(...) Autor czasami nie potrafi sprostać roli dyrygenta różnobrzmiącego chóru (Witosz, www.rjp.pl).

Anna Duszak (2015) podkreśla, że idea tożsamości akademickiej jest nieodłącznie związana z koncepcją , ,akademickiej wspólnoty dyskursu” oraz z pojęciem „dyscypliny naukowej” jako monokultury akademickiej. Tekst akademicki pełni funkcje identyfikacyjne - ujawnia style kulturowe ale też ujawnia przynależność do określonej dyscypliny wiedzy i pozycjonuje strukturalnie piszącego we wspólnocie, gdy weźmiemy pod uwagę kompetencje meta dyskursywne członków wspólnoty.

Dookreślając istotę humanistycznej tożsamości pedagogiki, Lech Witkowski pisze: „pedagogika jest ośrodkową dyscypliną meta-humanistyczną (...) jej kardynalną, centralną i wyjątkową powinnością jest dokonywanie refleksji teoretycznej także w zakresie sposobu pojmowania i praktycznego wdrażania wizji humanistycznej (humanizmu) własnego posłania i skutków szczytności własnych intencji” (Witkowski 2000, s. 235). Autorka znanego podręcznika pedagogiki ogólnej - Teresa Hejnicka-Bezwińska (2008, s. 258-302) językowi współczesnej pedagogiki poświęciła rozdział szósty swojej pracy. Problem języka pedagogiki jest, w przekonaniu badaczki, jedną z najbardziej podstawowych kwestii (Hejnicka-Bezwińska 2008, s. 260), albowiem w późnej nowoczesności język jest aktywnym czynnikiem kreowania świata społecznego i najważniejszym narzędziem działań społecznych. Działania językowe wiążą się z wiedzą o edukacji oraz z jej upowszechnianiem. Lawinowy przyrost wiedzy naukowej staje się powodem rozbieżności pomiędzy stylem języka, używanym w praktyce przez przeciętnego człowieka, a językiem naukowym, którym posługują się przedstawiciele różnych dyscyplin naukowych (Hejnicka-Bezwińska 2008, s. 258). Współczesne nauki humanistyczne oscylują pomiędzy dwoma skrajnymi stanowiskami: pozytywistycznym scjentyzmem i humanistyczną literackością, w sprawie poziomu naukowości, w odniesieniu do wiedzy wytwarzanej, przekazywanej i popularyzowanej w humanistyce. Językowy obraz rzeczywistości edukacyjnej może być tworzony zarówno w społecznej praktyce edukacyjnej, jak i w procesie wytwarzania naukowej wiedzy o edukacji. Ważne jest jednak, aby możliwe było komunikowanie się ze sobą obu przedstawicieli tych światów. Współczesny językowy obraz rzeczywistości edukacyjnej jest bardziej podobny do biblijnej wieży Babel; z tego powodu pedagogika jako dyscyplina naukowa zobowiązana jest do tworzenia systemu językowego, który w najogólniejszej postaci tworzy mapę pojęciową opisującą przedmiot badań. Zdaniem HejnickiejBezwińskiej, język pedagogiki, jako wytwór człowieka związanego ze społeczną praktyką edukacyjną (pedagogią), bliższy jest stylowi potocznego mówienia i myślenia o edukacji. Natomiast język pedagogiki jako nauki, która przedmiotem swoich badań czyni społeczną praktykę, musi korespondować z językiem współczesnych nauk humanistycznych. Aby opisać złożone związki między tymi dwoma stylami wypowiadania się (opisywania, wyjaśniania i interpretowania) o rzeczywistości edukacyjnej, pedagogika ogólna musi zatem poszukiwać i posługiwać się swoistą 
formą metajęzyka. Współtworzą go: język pedagogiki ogólnej, język subdyscyplin pedagogicznych (specjalizacji), język paradygmatu pozytywistycznego oraz język paradygmatu postpozytywistycznego (Hejnicka-Bezwińska 2008, s. 301).

Bogusław Bieszczad (2013) zarysował autorską i filozoficzną perspektywę analizy języków pedagogiki w dwóch planach teoretycznych: wertykalnym i horyzontalnym, wyznaczonych przez modernistyczny i postmodernistyczny model pedagogiki. Perspektywa wertykalna ma charakter waloryzujący i hierarchizujący, można w nią wpisać w ujęciu historycznym: język jedyny i opozycyjny, multijęzyki, parajęzyki i inne znane opozycje. Badacz kategorii ponowoczesnego języka pedagogiki zaproponował włączenie do dyskursów pedagogiki i jej języka perspektywy horyzontalnej, rezygnującej z waloryzacji języków na rzecz promocji wielości opisów. Jest to wizja pedagogiki ponowoczesnej, ściśle związanej z kulturą i humanistyką ujmowaną jako sfera semiotyczna, zdecentrowana, ujawniająca się na „pograniczach dyskursu, wartościowa zarówno pod postacią wiedzy naukowej, jak i w formule literatury, parodii i metafory, niestroniąca od narracji, zastępującej teorię i retoryki, konkurującej ze ścisłością" (Bieszczad 2013, s.126). Wertykalna perspektywa językowa operuje głownie kategoriami, nie waloryzując ich wobec pojęć, dopuszcza język „metaforyczny”, nie kwestionując ścisłego języka nauki, nie deprecjonuje języka „potocznego”, podobnie jak uznaje wartość języka „literackiego”, z jego figuralnością i retoryką, rozważa i promuje kategorie „,antyfundamentalistyczne” i „antyesencjalistyczne” (przygodności) w językowym konstruowaniu świata edukacji w jego językowo-przestrzennej formule ponowoczesnej, w której ważny jest także „działaniowy (performatywny)” wymiar możliwości języka. Ze względu na ograniczoną przestrzeń wywodu pomijam charakterystykę pięciu kategorii (wraz z ich egzemplifikacjami) opisanych na kartach książki B. Bieszczada (2013, s. 123-173).

Alina Wróbel przeanalizowała (stosując kryterium leksykalno-semantyczne) zmiany podstawowych kategorii badawczych, jakie dokonały i dokonują się w zakresie podstawowych pojęć pedagogicznych, w okresie od 1989 roku, oraz konsekwencje, jakie niesie ze sobą zjawisko zmiany języka współczesnej pedagogiki dla uprawiania pedagogiki, jej tożsamości i statusu jako dyscypliny naukowej. Wybrane przykłady procesów urzeczywistniających tę zmianę to np. model dziesięciościanu edukacji, zaproponowany przez Zbigniewa Kwiecińskiego. Stosunkowo czesto analizowane są: uczenie się jako centralna kategoria pojęciowa współczesnej praktyki edukacyjnej czy edukacja alternatywna; kategoria Innego jako uczestnika procesów edukacyjnych, postać lidera oświaty, fenomen wolnego rynku edukacyjnego, osoba edukatora, określenie - ekonomizacja działalności edukacyjnej. Wyraźnie zauważalny jest wzrost znaczenia takich kategorii badawczych, jak np. ambiwalencja, autonomia, dyskurs, emancypacja, opór, podmiot, podmiotowość. Język pedagogiki ma takie cechy, jak np. rzeczywistość społeczno-kulturowa, w której powstaje, konkluduje A. Wróbel (2018). Cechuje go wielość, różnorodność i wieloznaczność. Warto pamiętać, że niejednorodność i złożoność metodologiczna pedagogiki staje 
się często źródłem błędów popełnianych nie tylko przez początkujących badaczy. Bogusław Śliwerski (2017) uczynił obiektem diagnozy poziom naukowych kompetencji pedagogów przez pryzmat recenzji ich rozpraw doktorskich i habilitacyjnych. Zwrócił uwagę, że styl pisania rozpraw może rzutować na krytyczny ich odbiór. Błędna struktura narracji przejawia się w skłonności do nieznośnych powtórzeń, przykładów, myśli, zdań. Brak wielostronnego namysłu rozpoznawalny jest wówczas, gdy autor całkowicie stroni w swoim tekście od własnego komentarza do przedstawionych koncepcji, nie porządkuje ich według ważności lub nieustannie powraca do problemów uznawanych aktualnie za modne oraz do myślicieli o głośnych nazwiskach (Śliwerski 2017, s. 52). Dość często w pracach naukowych spotkać można beztroskie zestawianie obok siebie i jednoczesne wykorzystywanie sprzecznych orientacji teoretycznych, np. humanistycznej koncepcji człowieka z koncepcją behawioralną. Inny typowy błąd to cytowanie rozmaitych definicji, a następnie tworzenie własnej na zasadzie idem per idem, oraz ignotum per ignotum. Stanisław Juszczyk (2017) z kolei przestrzega przed błędami ekologizmu, indywidualizmu, redukcjonizmu oraz przesadną wiarą w wyniki badań ankietowych.

Jak już zostało powiedziane, to książka jest w naukach humanistycznych i społecznych „złotym standardem”, stanowi kontynuację najpiękniejszych intelektualnych kulturowych tradycji, podczas gdy artykuły wpisują się w zorientowaną na „wydajność" logikę działania korporacji (Melosik 2019b, s. 64). Status naukowca jest uzyskiwany poprzez ważne książki, jakkolwiek wysoko punktowane artykuły odgrywają istotną rolę $\mathrm{w}$ formalnej ewaluacji, to jednak nie pozwalają autorom znacząco zwiększyć statusu, dają bowiem „krótkotrwały skok pozycji” (Melosik 2019b, s. 93). Pedagodzy piszący o swoim powołaniu uniwersyteckim (Dudzikowa, Nowak 2015) w pełni zgadzają się co do jednej kwestii - pasji, która stanowi integralną część rdzenia tożsamości naukowca i jest „stanem serca i umysłu”, który warto pielęgnować niezależnie od okoliczności (Melosik 2019b, s. 164). Jeden z najwybitniejszych polskich uczonych przełomu XX i XXI wieku, badacz temperamentu i różnic indywidualnych, profesor psychologii Jan Strelau, potwierdził, że w pracy naukowca najważniejsza jest motywacja wewnętrzna i pasja, polegająca na tym, że człowiek nosi w swoim umyśle idee, koncepcje, rozwiązania i w dzień i w nocy. Profesor uwydatnił wagę książek autorskich, których napisanie wymaga wielu godzin siedzenia przy biurku, ale wymienił też osobę zacnego profesora Adama Frączka w roli przykładu wybitnego w skali międzynarodowej badacza agresji, który w swoim życiu nie opublikował żadnej książki autorskiej, a jest dobrze rozpoznawalny w świecie nauki ${ }^{3}$.

3 Zob. https://youtu.be/7uwxgEveItU. 


\section{Naukowiec epoki postpiśmiennej w wizji Jacka Dukaja}

Po piśmie Jacka Dukaja (2019) jest esejem o różnicach i konsekwencjach różnic między „myślunkami”. W historycznym przebiegu rozwoju pisma kluczowe są dwa momenty, dwie rewolucje: pierwsza to wykształcenie alfabetu, pośród mnogości pism niealfabetycznych. I druga: całkowite upodmiotowienie przez Greków pisma alfabetycznego, dzięki wprowadzeniu zapisu samogłosek. Po epoce druku i cywilizacji zaawansowanych technologii stajemy u progu trzeciego „myślunku”", dostępnego poprzez narzędzia umożliwiające już nie znaki przeżyć, lecz same przeżycia. Ów charakterystyczny zbiór nawyków i zdolności Dukaj nazywa „myślunkiem”. W dziejach człowieka wyróżnić można trzy epoki: kulturę oralną, kulturę pisma i kulturę bezpośredniego transferu przeżyć. Relację tych trzech form człowieczeństwa lepiej oddaje ciąg: mowa - pismo - technologie bezpośredniego transferu przeżyć. Oba pierwsze „myślunki” opierają się na tej samej zasadzie symbolicznego kodowania znaczeń, tj. na języku. Dopiero technologie transferu bezpośredniego pozwalają pominąć język: przeskoczyć etapy przekazu symbolicznego.

Pisarz-futurysta przyjął w swoim eseju (Dukaj 2019, s. 186-187) następujące założenia:

1. Znajdujemy się w okresie przejściowym między kulturą pisma i kulturą postpiśmienną; 2. Dominacje kolejnych metod transferu przeżyć ustanawiają w dziejach człowieczeństwa trzy epoki: epokę oralną, epokę pisma, epokę bezpośredniego transferu przeżyć; 3. Siła i głębokość wpływu dominującej metody transferu przeżyć na umysł Homo sapiens są tak duże, że uczciwiej byłoby mówić o trzech człowieczeństwach warunkowanych przez różnice w tych nawykach i mocach umysłu; 4. Każdy „myślunek” wprost oraz poprzez związane z nim technologie (bądź ich brak) wpływa lub wręcz determinuje kształt społeczeństwa, kultury, porządku ekonomicznego, politycznego, aż do moralności, estetyki i najintymniejszych doświadczeń człowieka. „Myślunek” poprzedza i warunkuje umysłowość i światopogląd, można go ujmować jako mindstyle - zwrócony do wewnątrz umysłu odpowiednik lifestyle, który jest czymś więcej niż jedynie stylem życia; 5. Im doskonalsza metoda transferu przeżyć, tym większą niepodległość ona zyskuje wobec tych, co je przeżywają (przeżywaczy); 6. Wartości postpiśmiennego przeżywacza nie są wartościami dziecka kultury pisma. Nie da się z wnętrza jednego „myślunku” oceniać ani planować innego „myślunku”. Co dobre lub złe, co piękne i co „brzydkie”, nie daje się przeszczepiać z jednego kontynentu myśli na drugi.

4 Michał Tabaczyński w eseju recenzyjnym książki Jacka Dukaja przekonuje, że w socjologii na określenie takiego zestawu dyspozycji istnieje całkiem pojemna nazwa habitus, autorstwa Pierre'a Bourdieu. 
Człowiek wychowany w piśmie właściwie nie może myśleć o postpiśmienności jako o nowym barbarzyństwie i upadku kultury. Życie w kulturze zdominowanej przez taką, a nie inną metodę transferu przeżyć kształtuje nas w wymiarach mentalnych i praktycznych, $\mathrm{z}$ pozoru zupełnie $\mathrm{z}$ tą metodą niezwiązanych, zarówno w sprawach błahych i codziennych, jak i w uczuciach najgłębszych, w najdonioślejszych wartościowaniach. Owa metoda ukształtowała i napędziła całą tę kulturę, która stanowi formę i treść naszego życia w świecie materii i życia duchowego, my zaś nie jesteśmy świadomi, jak piśmienność powoduje naszymi logikami, snami, wyborami, odruchami, upodobaniami, instytucjami i naukami.

Urodzony dla powietrza i nieprzerwanie oddychający powietrzem, nie czujesz powietrza; nie potrafisz sobie wyobrazić «bezpowietrzności». Urodzony w myślunku, nie myślisz o nim; nie potrafisz myśleć bez niego, na zewnątrz niego (Dukaj 2019, S. 189).

Pismo jest technologią i służy określonym celom. Jego używanie niesie ze sobą określone koszty i określone korzyści. Pismo wywołuje konkretne zmiany w strukturze społecznej, w kulturze, w „myślunku” (Dukaj 2019, s. 196). Jako gatunek ludzki posiadamy „instynkt interakcji”, który Dukaj nazywa „instynktem wyzewnętrzniania przeżyć"s. Istnieje w ludziach dążność, potrzeba i siła poprzedzająca i język i pismo, i technologie bezpośredniego przekazywania przeżyć.

Styl życia zmienia się fundamentalnie i nieodwracalnie.

Nie napiszę listu - zadzwonię. Nie przeczytam powieści - obejrzę serial. Nie wyrażę politycznego sprzeciwu w postaci artykułu - nagram filmik i wrzucę go na You Tubie. Nie spędzam nocy na lekturze poezji - gram w gry. Nie czytam autobiografii - żyję życiem celebrytów na Instagramie. Nie notuję nagrywam. Nie opisuję - fotografuję. I tak dalej... (Dukaj 2019, s. 235)

Nikt nie zmusza ludzi do takich wyborów, wydają się one po prostu naturalne. Jako szeregowi pracownicy naukowi trawimy i produkujemy masy dokumentów tekstowych. Z każdego szczebla na szczebel wyżej wędruje przekaz już przefiltrowany, stężony, sprofilowany. Współczesnym odpowiednikiem intelektualnej biografii profesora jest wystąpienie na TED i prezentacje audiowizualne. Autouzupełnianie, tak męczące w trakcie pisania smsów, stało się pisaniem. Pismo nie potrzebuje dziś piszącego.

Czytanie i piśmienność Dukaj rozszczepia na dwa zakresy znaczeniowe. $\mathrm{W}$ pierwszym $\mathrm{z}$ nich chodzi o umiejętność czytania na poziomie elementarnym, w drugim zaś o zdolność do pracy w głębokim „myślunku” pisma, do przyswajania

5 Arystoteles nazywał to „instynktem społecznym”, zaś Steven Pinker (1994) nazwał to samo „instynktem językowym”. 
i tworzenia długich, złożonych tekstów, operowania na ich treści, ich logicznej strukturze: o zdolność do myślenia pismem ${ }^{6}$. Takie myślenie jest znacznie szybsze od myślenia językowego, porównuje się je do myślenia obrazowego, śnienia na jawie

By odnieść życiowy i zawodowy sukces we współczesnym świecie, nie musisz już umieć czytać i pisać. (...) Albo oglądasz i słuchasz albo jesteś wykluczony (Dukaj 2019).

Dukaj stwierdza, że przekaz audiowizualny przejął tradycyjna rolę dyskursu prasowego i eseistycznego. Główne bitwy toczą się w przestrzeni You Tube, podcastów, mediów społecznościowych, internetu, telewizji.

Na globalnej agorze idee ucierają się nie na papierze, lecz w transmitowanym obrazami i dźwiękami cyrku awatarów idei (Dukaj 2019, s. 256).

Odpowiednio zmienia się pozycja i ścieżka kariery public intelectuals, jak również miejsce w niej książki. Model „kariery książki” czy droga książki obowiązująca w tym okresie przejściowym - tj. do momentu przejęcia w życiu publicznym wszystkich kierowniczych ról przez przedstawicieli pokoleń już wychowanych w „myślunku” transferu przeżyć wygląda następująco:

1. Obecność autora $\mathrm{w}$ mediach społecznościowych silnie audiowizualnych (You Tube, Instagram, Facebook itp.);

2. Wydanie książki, które daje pretekst, aby autor pojawił się $\mathrm{w}$ „starych mediach", jak telewizja, i wytworzone w ten sposób materiały audiowizualne wpuszczał w nowoczesne media transferu przeżyć;

3. Powoduje to dalszy wzrost followingu i intensywności przeżywania autora przez followerów;

4. To zaś pozwala na organizację zyskownych wystąpień publicznych i magnetyzację poularności na sposoby inne niż książka;

5. Tym samym proporcjonalnie zwiększa się ekspozycję idei, których taki autor jest nośnikiem (awatarem).

Model ten w obiegu anglosaskim stał się normą. Książka powstaje więc jako produkt uboczny komercyjnego łańcucha cywilizacji postpiśmiennej, służy za token: coś, co autor przekazał swoim przeżywaczom bardziej jako materialny symbol niż nośnik doświadczeń, tudzież wiedzy. Jednakże książka to wciąż najprostszy, najpopularniejszy sposób, aby spieniężyć popularność budowaną $\mathrm{w}$ sieciach transferu przeżyć.

6 Coraz więcej osób ze szczytów hierarchii sukcesu przyznaje się publicznie do dysleksji, być może dlatego że daje ona przewagę, dlatego że dyslektycy szybciej orientują się w świecie, szybciej się uczą, są bardziej twórczy, gdyż ich myślenie nie jest spętane pismem, językiem; myślą od razu pakietami wrażeń zmysłowych przeżyć. 
Obszary, w których Jacek Dukaj znajduje nisze literatury pisanej, to:

1. Formalizm języka, który w postaci krystalicznej ujawnia się w poezji. Słowo jest tu ogniskiem przeżycia. Brzmienie słowa, jego estetyka na kartce papieru, podświadome skojarzenia wizualne, rytmy składni i harmonie akapitów, kadencje wywodu, barwność i bujność stylistyki do ujęcia jedynie przez wzrok;

2. Życie wewnętrzne, czyli krajobrazy ducha stworzone przez słowo pozbawione desygnatów $\mathrm{w}$ świecie pozasłownym;

3. Przemijanie, fenomen odchodzenia w przeszłość. Upływu czasu nie można zobaczyć, dotknąć, usłyszeć. Naturalnym czasem narracji pisanej jest czas przeszły, zaś narracji oralnej - czas teraźniejszy. Przeżycie stuletniego życia nie odbija się w przeżyciu dwugodzinnego filmu o stu latach życia;

4. Pismo jest również pierwszym ogrodem myślenia logicznego, abstrakcyjnego, cieplarnią idei. Jest jedynym możliwym metabolizmem eseju i wszelkich podobnych splotów Logosu i Mythosu.

\section{Zakończenie}

Związki pisarstwa artystycznego i naukowego oraz trud związany z tworzeniem tekstu, wypowiedzi literackiej i naukowej uznano w przedstawionym artykule za złożone, ale jednocześnie podobne czynności umysłu poznającego i konstruującego znaczenia. Twórcy, którzy sztukę pisania opanowali do perfekcji, odnajdują się w świecie nauki i fikcji literackiej Pisanie akademickie ma wymiar indywidualny i społeczny - jest z jednej strony osadzone w doświadczeniu piszącego, jego sposobie interpretacji świata, $z$ drugiej natomiast jest włączane do społecznego obiegu, dlatego wymaga wielkiej odpowiedzialności etycznej. Rozwój technologii pisania wpływa na samo pisanie. Ewa Szczęsna (2013) pokazała mechanizmy reinterpretacji pisma i czytania w przestrzeni cyfrowej, które powodują zmianę sposobu doświadczenia tekstu. Współczesne techniki medialne sprawiają, że czytanie staje się pisaniem, pisanie staje się klikaniem (działaniem na teksturze), a klikanie doświadczeniem tekstu.

„Tekst, który powstaje bez wysiłku, czyta się bez przyjemności” (Samuel Johnson, cyt. za: Maćkiewicz 2010). Powinnością ludzi aspirujących do grona naukowców jest podejmowanie namysłu wielokrotnego, jego kluczowe znaczenie podkreślają zgodnie wszyscy piszący pedagodzy (Dudzikowa i in. 2015). Ten namysł jest konieczny, aby przekazywać swoje idee nie tylko elegancko, lecz także komunikatywnie i efektywnie. Napisanie tekstu naukowego, w tym pedagogicznego, wymaga, oprócz inteligencji i rozsądku, również cierpliwości i sumienności, starannego przygotowania i równie starannego poprawiania gotowej pracy. Istnieje całkiem pokaźna grupa akademików, którzy opanowali tę umiejętność w sposób mistrzowski i zdradzają sekrety swojej produktywności publikacyjnej. Pisarstwo naukowe opiera się na głębokiej ambiwalencji, którą wyrażają opozycyjne postawy 
„skończ to wreszcie” $i$ „nie spiesz się”. Dla dyscypliny jako całości ta ambiwalencja jest korzystna, ale dla poszczególnych naukowców już nie, mogą wiele stracić, jeśli dokonają nieodpowiednich wyborów (Bochno i in. 2013, Korzeniecka-Bondar 2017). Każdy tekst ma długą historię publikacyjną, poprzedzoną oczekiwaniami w redakcjach na recenzje, decyzje, korekty, kontakty z redaktorami prowadzącymi. Każdy opublikowany przez redakcję czasopism artykuł sprawia satysfakcję i motywuje do pisania następnych tekstów. Uzyskanie pozytywnych recenzji bardzo cieszy, czasem martwi, ponieważ jeśli brak jakichkolwiek uwag, to u piszącego rodzi się obawa, czy recenzenci w ogóle czytali pracę, a czytanie recenzji krytycznych własnych tekstów choć czasami zawstydza, jednocześnie zmusza do przemyślenia stanowiska, zmodyfikowania błędnych założeń. W pisaniu artykułów do czasopism naukowych najbardziej uciążliwy jest wymóg ograniczania długości tekstu do ściśle określonej liczby znaków, stron oraz nieprzewidywalny czas oczekiwania na recenzje. Napisanie tekstu o określonej liczbie znaków wcale nie jest łatwiejsze od pisania książki; wymaga niezwykłej umiejętności dyscyplinowania myśli, kondensacji treści i zachowania warunków intersubiektywnej komunikowalności.

Na zakończenie przytoczę garść cytatów poświęconych maestrii pisania. Guwernantka Vladimira Nabokova, „mrucząc pod nosem zwilża ustami błyszczącą stalówkę, zanim zanurzy ją w chrzcielnicy kałamarza” i „rozkoszuje się każdą nóżką każdej klarownej litery". W przekonaniu piszącej te słowa warto sumiennie pracować nad tekstem, a „ciężka praca wymaga wielu godzin” (Becker 2013, s. 141). „Spiesz się powoli i bez zniechęcenia po stokroć przekuwaj surowiec natchnienia" - pisał Nicolas Bolieau-Despreaux (cyt. za: Maćkiewicz 2010). Kiedyś jednak trzeba skończyć dzieło, gdyż jak zachęca Julia Hartwig, ...zrób, co zamierzałeś, bo nigdy nie będziesz gotowy, wezwij dobre duchy, żeby Ci sprzyjały" (Siła i słodycz. W: Zapisane).

\section{Bibliografia}

Becker H.S. (2013). Warsztat pisarski badacza. Warszawa: Wydawnictwo Naukowe PWN.

Bieńczyk M. (2011). Książka twarzy. Warszawa: Świat Książki.

Bieszczad B. (2013). Pedagogika i język: perspektywa ponowoczesna. Kraków: Wydawnictwo Uniwersytetu Jagiellońskiego.

Bochno E., Dudzikowa M., Grzybowski P., Kola A.M. i in. (2013). Młodzi badacze o swoim doświadczeniu związanym $z$ doskonaleniem warsztatu naukowego i pisarskiego: (panel dyskusyjny). „Przegląd Badań Edukacyjnych”.

Boruszewski J. (2017). Dostępność wiedzy naukowej a jej intersubiektywna komunikowalność. W: Komunikacja naukowa w humanistyce. Poznań: Wydawnictwo Naukowe IF UAM.

Duda B., Przyklenk J., Sujkowska-Sobisz K. (2019). Reprezentacje humanistyki cyfrowej w polskim dyskursie naukowym. W: Reprezentacje świata $w$ dyskursach 
(modele, obrazy, wizje). Ciesek-Ślizowska B., Duda B., Ficek E., Sujkowska-Sobisz K. (red.). Katowice: Wydawnictwo Uniwersytetu Śląskiego, s. 55-69).

Dudzikowa M., Nowak M., Heller M. (2015). O pasjach cudzych i własnych Profesorowie. Lublin: Wydawnictwo KUL.

Dukaj J. (2019). Po piśmie. Warszawa: Wydawnictwo Literackie.

Duszak A. (2015). Wielogłosowość języków nauki a tożsamość akademicka w świetle lingwistyki stosowanej. W: Tekst naukowy i jego przekład. Duszak A., JopekBosiacka A., Kowalski G. (red.). Kraków: Universitas, s. 79-107..

Eco U. (2007). Jak napisać pracę dyplomową: Poradnik dla humanistów. Tygielski W. (red.). Jurkowlaniec G. (tłum.). Warszawa: Wydawnictwa Uniwersytetu Warszawskiego.

Ficek E. (2013). Poradnik, model gatunkowy i jego tekstowe aktualizacje. Warszawa: Wydawnictwo Uniwersytetu Śląskiego.

Gajda S. (2001). Styl naukowy. W: Współczesny język polski. Bartmiński J. (red.). Lublin: Wydawnictwa Uniwersytetu Marii Curie-Skłodowskiej, s. 183-199.

Gajda S. (2017). Język w nauce: (w perspektywie filozoficzno-lingwistycznej). „Parezja”, nr 2, s. 9-20.

Hall S. (2013). Representation: Cultural representations and signifying practices. London: Sage The Open University.

Hejnicka-Bezwińska T. (2008). Pedagogika ogólna. Warszawa: Wydawnictwa Akademickie i Profesjonalne.

Iwasiów I. (2020). Odmrażanie. Literatura w potrzebie. Szczecin: Uniwersytet Szczeciński.

Janion M. (1997). Kuferek Harpagona. „«Teksty Drugie» - teoria literatury, krytyka, interpretacja", $\mathrm{nr}$ 1/2, s. 199-217.

Język współczesnej humanistyki (200o). Pelc J. (red.). Warszawa: „Znak, Język, Rzeczywistość" Polskie Towarzystwo Semiotyczne.

Juszczyk S. (2017). Niejednorodność i złożoność metodologiczna pedagogiki a potencjalne błędy popełniane przez badacza. W: Pułapki epistemologiczne i metodologiczne w badaniach nad edukacją: jak sobie z nimi radzić? (wykłady profesorów wygłoszone na XXX Letniej Szkole Młodych Pedagogów przy KNP PAN, 2016). Wisła, s. 56-79.

Korzeniecka-Bondar A. (2017). O trudnościach w pisaniu: Uwagi na marginesie lektury tekstów przesłanych do redakcji Parezji. „Parezja”, s. 127-137.

Koziołek R. (2016). Dobrze się myśli literaturą. Wołowiec: Wydawnictwo Czarne.

Kubinowski D. (2006). Pedagogiczne myślenie humanistyczne jako kategoria metodologiczna. W: Metodologia pedagogiki zorientowanej humanistycznie. Kubinowski D., Nowak M. (red.). Kraków: Polskie Towarzystwo Pedagogiczne.

Łompieś J.B. (2018). Refleksja metapoznawcza w procesie kształtowania sprawności pisania. „Półrocznik Językoznawczy Tertium”, nr 3 (2).

Maćkiewicz J. (2010). Jak dobrze pisać: Od myśli do tekstu. Warszawa: Wydawnictwo Naukowe PWN. 
Melosik Z. (2019a). Książka jako „złoty standard” w naukach humanistycznych i społecznych. „Studia Edukacyjne”, nr 52, s. 7-22.

Melosik, Z. (2019b). Pasja i tożsamość naukowca: O władzy i wolności umysłu. Poznań: Wydawnictwo Naukowe UAM.

Mikołajczak M. (2013). Pomiędzy końcem i apokalipsą: O wyobraźni poetyckiej Zbigniewa Herberta (wyd. 2).Toruń: Wydawnictwo Naukowe Uniwersytetu Mikołaja Kopernika.

Pinker S. (2016). Piękny styl. A. Nowak-Młynikowska (tłum.). Sopot: Wydawnictwo Smak Słowa.

Richardson L., St. Pierre E.A. (2009). Pisanie jako metoda badawcza. W: Metody badań jakościowych. Norman K., Denzin K., Lincoln Y.S., Podemski K. (red.). T. 2. Warszawa: Wydawnictwo Naukowe PWN, s. 457-482.

Szczęsna E. (2013). Piśmienne bycie w przestrzeni cyfrowej: Wspótczesne ślady tożsamości. „Zagadnienia Rodzajów Literackich”, nr 56, s. 17-32.

Śliwerski B. (2017). Błędy metodologiczne w awansowych publikacjach pedagogów. W: Pułapki epistemologiczne i metodologiczne w badaniach nad edukacją: jak sobie z nimi radzić? (wykłady profesorów wygłoszone na XXX Letniej Szkole Młodych Pedagogów przy KNP PAN, 2016). Wisła, s. 41-55.

Witkowski L. (2000). Edukacja i humanistyka : nowe konteksty humanistyczne dla nowoczesnych nauczycieli. Warszawa: Instytut Badań Edukacyjnych.

Witkowski, L. (2007). Między pedagogika, filozofia i kultura : studia, eseje, szkice. „Tryptyk edukacyjny”. T. 3. Warszawa: Instytut Badań Edukacyjnych.

Wróbel A. (2018). Język wspólczesnej pedagogiki w perspektywie komparatystyki myśli pedagogicznej: wybrane przykłady zmian leksykalnych. „Forum Pedagogiczne”, nr 1, s. 93-103.

Żyrek-Horodyska E. (2019). Kartografowie codzienności: O przestrzeni (w) reportażu. Kraków: Instytut Dziennikarstwa, Mediów i Komunikacji Społecznej Uniwersytetu Jagiellońskiego. 


\title{
REPRESENTATIONS OF WRITING IN PEDAGOGICAL HUMANISTIC THINKING
}

\begin{abstract}
The theme of the article is the praxis of writing. The winters of the Nobel Prize in literature and brilliant minds of creative writing have sophisticated text-creating skills. A significant group of writers are left with a lifelong development and improvement of this skill. Thanks to the fact that the writers and academics themselves reveal to the world the secrets of their reading biographies and reveal to us the secrets of their own art of writing, learning from masters is quite real. The aim of the article is to present self-referential statements about the writing of selected Polish writers, authors of art writing guides and educators These propositions and presented images are in fact cultural representations of writing. At the end of the study, Jacek Dukaj's futuristic visions were recalled. It was recognized that the post-literacy era in which we live today constitutes an important context for contemporary and future academic writing.
\end{abstract}

Keywords: art of writing, textual metacompetence, post-literacy. 